\title{
Tank mixture of pesticides and foliar fertilizes for Triozoida limbata control in guava trees (Psidium guajava $\left.\mathrm{L}_{\text {. }}\right)^{1}$
}

\author{
César Henrique Souza Zandonadi $i^{*} \mathbb{D}$, Thales Cassemiro Alves ${ }^{2}$; Heli Heros Teodoro de Assunção ${ }^{2}$, Guilherme \\ Sousa Alves ${ }^{2}$, Sergio Macedo Silva ${ }^{3}$, João Paulo Arantes Rodrigues da Cunha ${ }^{2}$
}

10.1590/0034-737X201966040008

\begin{abstract}
Although the tank mixture of pesticides and foliar fertilizers is common practice in agriculture, further clarification and scientific support is needed to be regulated. Thus, the objective of this work was to evaluate the effect of tank mixture of an organosilicon adjuvant and manganese foliar fertilizer throw the insecticide imidacloprid effectiveness over Triozoida limbata control in guava trees. The experimental plot was considered with four trees followed in the same cultivation line subdivided into 4 quadrants. The experiment followed a randomized block design with split plots, with four replications. Treatments were T1 - Imidacloprid (Imid.); T2 - Imid. + Polyether-polymethyl siloxane copolymer (Sil.); $\mathrm{T} 3$ - Imid. $+\mathrm{MnSO}_{4}$; $\mathrm{T} 4$ - Imid. + Sil. $+\mathrm{MnSO}_{4}$; $\mathrm{T} 5-\mathrm{Control}$ (no application). Physical-chemical characteristics, spray deposition over the leaves and losses to the soil, guava psyllid percentage of infestation and nymph's number were evaluated. The addition of foliar fertilizer on the mixture reduced the $\mathrm{pH}$ and surface tension and increased the electric conductivity and viscosity of the insecticide solutions. The silicon adjuvant reduced the surface tension and increased the viscosity and the $\mathrm{pH}$. The tank mixture of organosilicon adjuvant and manganese foliar fertilizer do not influence the efficacy level of the insecticide.
\end{abstract}

Keywords: Guava psyllid; physical-chemical characteristics; neonicotin; foliar fertilizer; organosilicon.

\section{INTRODUCTION}

The guava tree (Psidium guajava L.) stands out among the Brazilian tropical species, mainly by its flavor and nutritional value. To raise the quality of the product and thereby expand the production, the growers must overcome some obstacles as orchard conduction, problems with fertilization, application technologies as well as the high number of diseases and pests. One of the main problems for guava production is an insect, known as the guava psyllid (Triozoida limbata - Hemiptera: Triozidae) (Galli et al. 2014; Barbosa \& Lima, 2010).

The characteristic symptom of guava psyllid attack is the winding from the edges of the leaves, where colonies of nymphs stays. With this attack the leaves could fall, compromising the production (Barbosa et al., 2001; Gallo et al., 2002). According to Colombi \& Galli (2009) the importance of this psyllid has probably increased because of the adopted production system, with more irrigation and tree pruning, that favors the psyllid population growth because of the abundant number of new sprouts.

'Paluma' is one of the most used cultivars in Brazilian orchards mainly because it presents capacity to produce fruits even to industry and in natura use (Farias et al., 2017). This cultivar does not present resistance to the attack of guava psyllid that became one of the main problems for its production (Barbosa \& Lima, 2010).

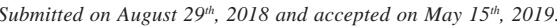

${ }^{1}$ This work is part of the thesis of the first author.

${ }^{2}$ Universidade Federal de Uberlândia, ICIAG, Uberlândia, Minas Gerais, Brazil. cesarzandonadi@ufu.br; thalescalves@hotmail.com; heli_heros@hotmail.com; guilhermeagro43@yahoo.com.br; jpcunha@ufu.br

${ }^{3}$ Universidade Federal do "Vale do Jequitinhonha e Mucuri"; Campus Unaí, MG, Brazil. sergiomacedosilva@ yahoo.com.br

*corresponding author: cesarzandonadi@yahoo.com.br
} 
The use of pesticides is frequent during the guava cycle, mainly in tank mixture, a common practice in Brazilians fields, in order to keep the field productivity and reduce the application cost. The main problem is the uncertain effects that each mixture of different products can cause on the application (Gazziero, 2015).

Neonicotinoids, which are remarkably effective insecticides against sucking insect pests have been shown to effectively control the guava-psyllid before (Barbosa et al., 2001), does not present the same effect over this pest, as described by Lima \& Gravina (2009) that found an inefficacy of this product on high-density level of infestation after some time. Besides the efficiency decrease of the products, the association of different compounds within the spray tank can generate changes on the effectiveness of these products (Khaliq et al., 2012).

Tank mixture has been a very common practice, especially with the addition of adjuvants and foliar fertilizers. However, the effect of these blends was not well known. Physicochemical properties are altered with these mixtures and may influence the efficacy of plant protect products. Depending of the adjuvant composition and formulation, they could affect physicochemical characteristics of the spray, mainly $\mathrm{pH}$, surface tension and viscosity (Cunha \& Alves, 2009), which justifies the need for further studies to verify the behavior of these properties in relation to some mixtures and the possible biological effects.

The penetration and physiological effect of leafapplied nutrient sprays involves a series of intricate mechanisms ranging from the mode of application, to the physicochemical characteristics of the solution, the prevailing environmental conditions or the target plant species. There are many processes involved, which make difficult the development of new strategies to optimize the efficiency of foliar sprays under different conditions during the growing of the crops (Fernandez \& Eichart, 2009).

The adjuvants added to the mixture to enhance the efficiency act in different ways. They could improve greater spreading of the droplet and the wetting of the spray mixture over the target (Cunha et al. 2010A), as well as influence the penetration thru the cuticle (Wang \& Liu, 2007). However, despite of the advantages of adjuvants, it needs more clarification about it association with foliar fertilizer and the effects to efficacy of biological molecules, like insecticides.

Therefore, the objectives of this work were to evaluate the effect of tank mixture of an organosilicon adjuvant and manganese foliar fertilizer throw the insecticide imidacloprid effectiveness over T. limbata control in guava trees.

\section{MATERIAL AND METHODS}

\section{Experimental site}

The present work was carried out in duplicate (two periods of application) in a guava orchard ( $P$. guajava L.), 'Paluma' cultivar, at "Água Limpa" experimental farm (19 $6 ' 16,49^{\prime \prime S}$ e $\left.48^{\circ} 20^{\prime} 54,38^{\prime \prime}\right)$, belonging to the Federal University of Uberlândia (UFU), Uberlândia - MG - Brazil. According to Köppen classification, the area is characterized as Aw (tropical, hot humid area with cold and dry winter) with an altitude of $795 \mathrm{~m}$.

It was selected an area of production (nine years old), with 80 plants, spaced in $5.0 \mathrm{~m}$ between cultivation lines and $3.0 \mathrm{~m}$ between plants. The total experimental area presented about $1000 \mathrm{~m}^{2}$. The experimental plot was considered with four trees followed in the same cultivation line subdivided into 4 quadrants (Q1, Q2, Q3 and Q4). The two central trees were the useful plot and the borders were compounds by the first and the last trees. Each block presented 5 plots arranged linearly.

Treatments were applied with applications of $600 \mathrm{~L} \mathrm{ha}^{-1}$ at $0.46 \mathrm{~km} \mathrm{~h}^{-1}$. Q1 and Q3 were allocated in the same direction as the cultivation line, Q2 and Q4 were perpendicular (Figure 1). During the treatment applications, a plastic protection was used to avoid drift to adjacent plots in the direction of application.

The first period ( $1^{\text {st }}$ application) was conducted in the $2017 / 2018$ harvest, in December $14^{\text {th }} 2017$, a period of high infestation of guava psyllid. The second period in April $13^{\text {th }} 2018$ ( $2^{\text {nd }}$ application), after harvesting the fruits, the experiment was repeated in the same area, following the same methodology.

\section{Treatments}

Treatment solutions were prepared with one manganese salt (Manganese sulfate $-\mathrm{MnSO}_{4}$ ), one adjuvant (polyether-polymethyl siloxane copolymer) and one insecticide (Imidacloprid) at the Agricultural Mechanization Laboratory (LAMEC), from the Federal University of Uberlândia (UFU). The products specifications are in Table 1.

\section{Experiment conduction}

For the applications, a motorized pneumatic backpack sprayer (Stihl ${ }^{\circledR}$ SR450, 14 L tank and a 2900W engine) was used. Droplets are formed by action of the wind and in accordance with the setting of the orifice, which is the output of the spray (does not use a hydraulic nozzle). The engine was half accelerated in order to cause less drift and not overload it, presenting a flow rate of $1.45 \mathrm{~L} \mathrm{~min}^{-1}$.

The treatments application happens perpendicular at the cultivation line (Q2 and Q4 receive direct application) on both sides of the tree (Figure 1), and at distance of 
approximately $1.5 \mathrm{~m}$ between the sprayer and the tree. To avoid plots contamination was used during the application plastic canvas that covered the adjacent area. After the application, the collected samples (leaves and petri dishes) were analyzed at the LAMEC.

During the experiments the environmental conditions were monitored, on the first period, temperature $\left({ }^{\circ} \mathrm{C}\right)$ was between 23.7 - 27.5; for humidity (\%), 60.5 - 70.0; and 4.5 11.7 for wind speed $\left(\mathrm{km} \mathrm{h}^{-1}\right)$. On the second period, the temperature $\left({ }^{\circ} \mathrm{C}\right)$ vary between 23.9 - 29.1; humidity $(\%)$, 55.6 - 75.6; and $0.1-5.6$ for wind speed $\left(\mathrm{km} \mathrm{h}^{-1}\right)$.

\section{Evaluations}

\section{Physical-chemical evaluations}

Different tank mixtures were prepared with pesticide to evaluate the physical-chemical characteristics: density, $\mathrm{pH}$, electric conductivity (EC), viscosity (Visc.) and surface tension (ST). In the ways of comparison, it was evaluated distilled water. The evaluations were done as described elsewhere (Cunha et al., 2010B). The evaluations of physical-chemical properties were realized at LAMEC.

\section{Application technology evaluation}

For the evaluation of the application technology, each plot consisted of four plants and every useful plant was subdivided into four quadrants.

Two central plants formed the useful area of each plot, from which two leaves per quadrant were collected, resulting in 16 leaves per plot. These leaves were collected immediately after the applications from the middle third of the plants in the middle part of the canopy.

The evaluations of leaf deposition and the losses to the soil were described elsewhere (Tavares et al., 2017).

\section{Pest evaluation}

To check the psyllids level of infestation, the area was sampled one day before the first application. The evaluations were done at $7^{\text {th }}, 12^{\text {th }}$ and $14^{\text {th }}$ days after the application (Daa).
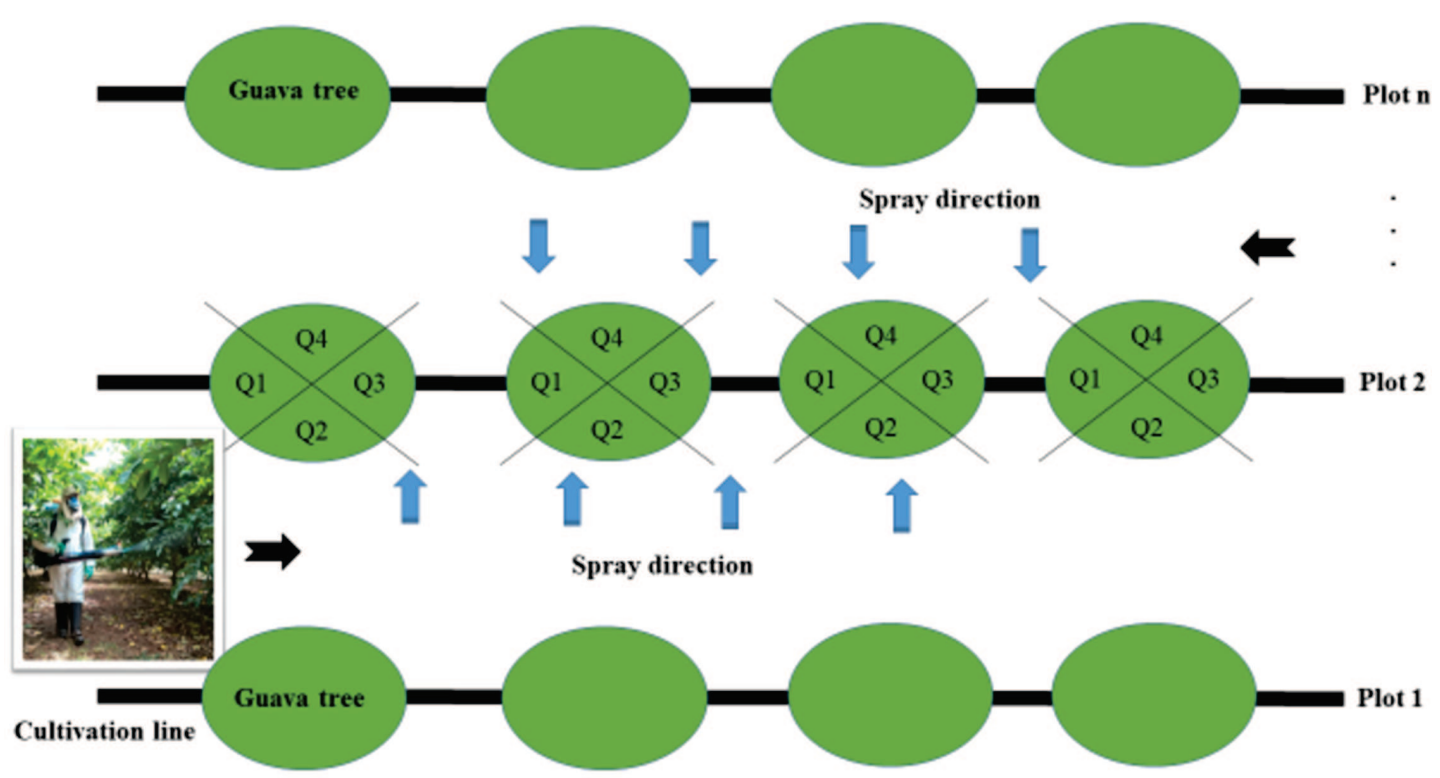

Figure 1: Detail of the experimental plot used for the application of the treatments and the direction of application used in relation to the subplots

Table 1: Specifications of pesticides (insecticide, adjuvant and foliar fertilizer) used for the application of the treatments and evaluation of tank mixture

\begin{tabular}{lccccc}
\hline Product & Active ingredient & Function & Concentration & *Formulation & Dose \\
\hline Provado $^{\circledR} \mathrm{SC} 200$ & $\begin{array}{c}\text { Imidaclopride (Imid) } \\
\text { Polyether-polymethyl } \\
\text { siloxane copolymer (Sil.) }\end{array}$ & Insecticide & $200 \mathrm{~g} \mathrm{~L}^{-1}$ & $\mathrm{SC}^{1}$ & $2.5 \mathrm{~mL} \mathrm{plant}^{-1}$ \\
Break Thru ${ }^{\text {Manganese }}$ & Adjuvant & $1000 \mathrm{~g} \mathrm{~L}^{-1}$ & $\mathrm{SC}^{2}$ & $0.1 \% \mathrm{v} \mathrm{v}^{-1}$ \\
Manganese sulfate & Fulfate $\left(\mathrm{MnSO}_{4}\right)$ & Foliar fertilizer & $30 \%$ & $\mathrm{PW}$ & $0.05 \%$ \\
\hline
\end{tabular}

*SC ${ }^{1}$ - Suspension concentrate; $\mathrm{SC}^{2}$ - Soluble concentrate; PW - Powder;

Treatments were T1 - Imidacloprid (Imid.); T2 - Imid. + Polyether-polymethyl siloxane copolymer (Sil.); T3 - Imid. + MnSO ; T4 Imid. + Sil. + $\mathrm{MnSO}_{4} ; \mathrm{T} 5$ - Control (no application). 
The two central trees from the plot were considered for efficacy sampling, as the first and the last tree considered as borders. The damage threshold of the guava psyllids was when $30 \%$ of the leaves justified spraying for pest management in the area. The samples evaluations were described by Tavares et al. (2017).

Then, with the aid of a digital microscope (Dino-lite pro model: AM - 413ZT) with 200x magnification, the number of psyllid nymphs was counted on each leaf, and the mean of the plot was calculated.

\section{Experimental design and statistical analysis}

The experiment was conducted in a casually delineated blocks with split-plot, with five treatments and four replications. The treatments were the plots and the quadrants (Q1, Q2, Q3 and Q4) constituted the subplots. The obtained data was submitted to normality test of normal distribution of errors (Shapiro Wilk) and homogeneity of variances from Levene, in 0.01 of significance.

The "F" test was performed to determine levels of significance of 0.05 and 0.01 for the analysis of variance. When these tests were significant, the averages were compared with the Scott-Knott test at 0.05 level of probability. When necessary data was transformed by $\sqrt{\mathrm{x}+1}$. All analysis was realized using SPSS software.

\section{RESULTS AND DISCUSSION}

\section{Physical chemical evaluations}

The physical chemical characteristics of the treatments changed according to each product added (Table 2). The adjuvant did not change EC in the treatment with only insecticide and provided a small increase in $\mathrm{pH}$. On the other hand, the foliar fertilizer reduced the $\mathrm{pH}$ and increased EC significantly. The values of density increased according to the addiction of products in the mixture, however, the magnitude of the changes was low. Andrade et al. (2013) found that some of these characteristics, mainly the $\mathrm{pH}$, were influenced by the addition of some foliar fertilizers.

The reduction of the spray $\mathrm{pH}$ after the addition of $\mathrm{MnSO}_{4}$ is due to the process of dissociation of this compound, releasing the $\mathrm{SO}_{4}^{-2}$ ion in solution, which in turn provides the $\mathrm{H}^{+}$ion, becoming the $\mathrm{pH}$ acidic. The increase of the EC values due to the addition of $\mathrm{MnSO}_{4}$ in the two treatments can also be explained by the dissociation of the inorganic salt, providing free $\mathrm{H}^{+}$ ions in the solution, capable of conducting the electric charge.

For certain molecules, such as some herbicides, the reduction of the spray $\mathrm{pH}$ is paramount to maintain the effectiveness of the product. During tank mixture, the presence of inorganic salts as foliar fertilizers cause incompatibility between molecules and effectiveness

Table 2: Physical chemical characteristics of the treatments

\begin{tabular}{lccccc}
\hline Treatments & Density $\left(\mathbf{g ~ L}^{-1}\right)$ & $\mathbf{p H}$ & $\mathbf{E C}\left(\boldsymbol{\mu S ~ \mathbf { ~ m } ^ { - 1 } ) ^ { + }}\right.$ & $\mathbf{V i s c} .\left(\mathbf{m P a ~ s}^{-1}\right)$ & $\mathbf{S T}\left(\mathbf{m N ~ m}^{-1}\right)$ \\
\hline Imid & $1.026 \mathrm{C}$ & $6.32 \mathrm{C}$ & $4.00 \mathrm{D}$ & $0.94 \mathrm{E}$ & $50.75 \mathrm{~B}$ \\
Imid+ Sil. & $1.029 \mathrm{~B}$ & $7.27 \mathrm{~A}$ & $4.75 \mathrm{D}$ & $1.06 \mathrm{~B}$ & $25.50 \mathrm{C}$ \\
Imid+ $\mathrm{MnSO}_{4}$ & $1.034 \mathrm{~A}$ & $4.55 \mathrm{D}$ & $1729.00 \mathrm{~B}$ & $1.02 \mathrm{C}$ & $26.50 \mathrm{C}$ \\
Imid+ Sil. + $\mathrm{MnSO}_{4}$ & $1.034 \mathrm{~A}$ & $4.30 \mathrm{E}$ & $1961.50 \mathrm{~A}$ & $1.13 \mathrm{~A}$ & $23.75 \mathrm{D}$ \\
Water & $1.024 \mathrm{D}$ & $6.85 \mathrm{~B}$ & $16.25 \mathrm{C}$ & $0.99 \mathrm{D}$ & $71.50 \mathrm{~A}$ \\
\hline $\mathbf{C V}$ & 1.31 & 2.55 & 1.91 & 0.91 & 3.07 \\
$\mathbf{F}$ & $15242.222^{*}$ & $329.026^{*}$ & $14700.377^{*}$ & $230.179 *$ & $1199.713^{*}$ \\
Flevene & $4.785 \mathrm{~ns}$ & $3.607 \mathrm{~ns}$ & $1.877 \mathrm{~ns}$ & $0.458 \mathrm{~ns}$ & $0.769 \mathrm{~ns}$ \\
SW & $0.956 \mathrm{~ns}$ & $0.920 \mathrm{~ns}$ & $0.934 \mathrm{~ns}$ & $0.946 \mathrm{~ns}$ & $0.939 \mathrm{~ns}$ \\
\hline
\end{tabular}

${ }^{+}$EC: data transformed $\sqrt{\mathrm{x}+1} ; \mathrm{CV}-$ Coefficient of variation; F- values of calculated F for different treatments. SW - Shapiro Wilk test. ${ }^{\mathrm{ns} ; *}$ - not significant; significant at 0,05.; Means followed by the same letter do not differ according to Scott Knott ( $\mathrm{p} \leq 0.05)$.

Table 3: ANOVA summary for application technology

\begin{tabular}{lccccc}
\hline & \multicolumn{2}{c}{$\mathbf{1}^{\text {st }}$ application } & & \multicolumn{2}{c}{$2^{\text {nd }}$ application } \\
\cline { 1 - 2 } \cline { 5 - 5 } & Deposition & Losses to the soil & & Deposition & Losses to the soil \\
\hline Ftreat & $4.776^{*}$ & $1.822^{\mathrm{ns}}$ & & $2.031^{\mathrm{ns}}$ & $4.473^{*}$ \\
Fquad & $7.719^{*}$ & $1.723^{\mathrm{ns}}$ & & $0.754^{\mathrm{ns}}$ & $5.839^{*}$ \\
Ftreat & & $2.416^{*}$ & & $0.715^{\mathrm{ns}}$ & $2.991^{*}$ \\
\hline Flevene & $0.345^{\mathrm{ns}}$ & $1.813^{\mathrm{ns}}$ & & $2.286^{\mathrm{ns}}$ & $2.077^{\mathrm{ns}}$ \\
$\mathbf{S W}$ & $2.234^{\mathrm{ns}}$ & $0.975^{\mathrm{ns}}$ & & $0.974^{\mathrm{ns}}$ & $0.948^{\mathrm{ns}}$ \\
\hline
\end{tabular}

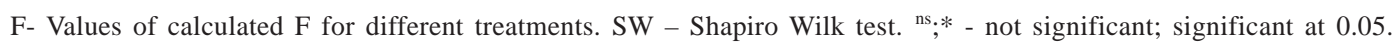

Rev. Ceres, Viçosa, v. 66, n.4, p. 297-306, jul/aug, 2019 
reduction (Bernards et al., 2005), something not yet relevant to other products, like neonicotinoids.

The products mixture reduced surface tension in relation to water, with emphasis on the foliar fertilizer and the adjuvant, which resulted in the lowest values. Foliar fertilizer had the potential to decrease surface tension, without the use of the adjuvant. Again, the dissociation process of the $\mathrm{MnSO}_{4}$ can explain the reduction of the

Table 4: Foliar deposition of tracer $\left(\mu \mathrm{g} \mathrm{cm}^{-2}\right)$ after treatment applications (First application)

\begin{tabular}{|c|c|}
\hline Treatments & Deposition $\left(\mu \mathrm{g} \mathrm{cm}^{-2}\right)$ \\
\hline Imid & $10.33 \mathrm{~A}$ \\
\hline Imid+ Sil. & $7.08 \mathrm{~B}$ \\
\hline $\mathrm{Imid}+\mathrm{MnSO}_{4}$ & $7.61 \mathrm{~B}$ \\
\hline Imid+ Sil. $+\mathrm{MnSO}_{4}$ & $5.54 \mathrm{~B}$ \\
\hline $\mathrm{CV}_{\mathrm{t}}$ & 47.80 \\
\hline
\end{tabular}

Table 5: Foliar deposition of tracer $\left(\mu \mathrm{g} \mathrm{cm}^{-2}\right)$ on each quadrant (First application)

\begin{tabular}{lc}
\hline Quadrant & Deposition $\left(\boldsymbol{\mu g} \mathbf{~ c m}^{-2}\right)$ \\
\hline 1 & $6.24 \mathrm{~B}$ \\
2 & $11.08 \mathrm{~A}$ \\
3 & $4.85 \mathrm{~B}$ \\
4 & $8.39 \mathrm{~A}$ \\
\hline $\mathbf{C V}$ & 53.08 \\
\hline $\mathrm{CV}$ - Coefficient of variation; q- values of quadrant; Means followed \\
by the same letter do not differ according to Scott Knott $(\mathrm{p} \leq 0.05)$.
\end{tabular}

superficial tension. This inorganic compound during the hydro-dissociation can reduce the strong intermolecular interactions inside the water molecule, because provide free $\mathrm{H}^{+}$ions to solution.

According to Iost \& Raetano (2010) the silicon adjuvants were more efficient in reducing the surface tension. This reduction was more pronounced due the association with $\mathrm{MnSO}_{4}$, that promotes a greater spread of the droplets on the target, which can favor its absorption.

Regarding viscosity, the addition of the fertilizer and the adjuvant to the insecticide increased its value. Higher viscosity of the spray results in larger droplet sizes. So, the addition of ions in the solutions had directly influence over these characteristics.

\section{Application technology}

From the analyzed variables for application technology, foliar deposition was significant $(\mathrm{P}<0.05)$ for treatments and quadrants only for the first period of application (Table 3). By the way, losses to the soil were significant between treatments and quadrants for both applications.

The tracer deposition in the first application was higher in treatment only with insecticide, differently from the others, that presented the same deposition standard (Table 4).

When the products were added with the insecticide, the values of surface tension were drastically reduced (Table 1). When the leaves were sprayed, the droplets

Table 6: Spray loss $\left(\mu \mathrm{g} \mathrm{cm}^{-2}\right)$ to the soil $\left(1^{\text {st }}\right.$ and $2^{\text {nd }}$ application $)$

\begin{tabular}{|c|c|c|c|c|}
\hline \multirow{3}{*}{ Treatments } & \multicolumn{3}{|c|}{$1^{\text {st }}$ application } & \\
\hline & \multicolumn{4}{|c|}{ Quadrants } \\
\hline & 1 & 2 & 3 & 4 \\
\hline Imid & $0.52 \mathrm{Aa}$ & $0.51 \mathrm{Ab}$ & $0.54 \mathrm{Aa}$ & $0.68 \mathrm{Aa}$ \\
\hline Imid+ Sil. & $0.63 \mathrm{Aa}$ & $0.26 \mathrm{Ab}$ & $0.30 \mathrm{Aa}$ & $0.56 \mathrm{Aa}$ \\
\hline $\mathrm{Imid}+\mathrm{MnSO}_{4}$ & $0.83 \mathrm{Aa}$ & $0.81 \mathrm{Aa}$ & $0.46 \mathrm{Aa}$ & $0.65 \mathrm{Aa}$ \\
\hline Imid+ Sil. $+\mathrm{MnSO}_{4}$ & $0.45 \mathrm{Aa}$ & $0.17 \mathrm{Bb}$ & $0.78 \mathrm{Aa}$ & $0.53 \mathrm{Aa}$ \\
\hline $\mathrm{CV}_{\mathrm{t}}$ & \multicolumn{4}{|c|}{77.31} \\
\hline $\mathrm{CV}_{\mathrm{q}}$ & \multicolumn{4}{|c|}{44.79} \\
\hline \multicolumn{5}{|c|}{$2^{\text {nd }}$ application } \\
\hline \multirow[t]{2}{*}{ Treatments } & \multicolumn{4}{|c|}{ Quadrants } \\
\hline & 1 & 2 & 3 & 4 \\
\hline Imid & $1.08 \mathrm{Aa}$ & $0.46 \mathrm{Ba}$ & $0.74 \mathrm{Ba}$ & $0.58 \mathrm{Ba}$ \\
\hline Imid+ Sil. & $0.38 \mathrm{Bb}$ & $0.19 \mathrm{Ba}$ & $0.89 \mathrm{Aa}$ & $0.68 \mathrm{Aa}$ \\
\hline Imid+ $\mathrm{MnSO}_{4}$ & $0.22 \mathrm{Ab}$ & $0.29 \mathrm{Aa}$ & $0.57 \mathrm{Aa}$ & $0.48 \mathrm{Aa}$ \\
\hline Imid+ Sil. $+\mathrm{MnSO}_{4}$ & $0.21 \mathrm{Ab}$ & $0.16 \mathrm{Aa}$ & $0.25 \mathrm{Ab}$ & $0.17 \mathrm{Aa}$ \\
\hline$\overline{\mathrm{CV}_{\mathrm{t}}}$ & \multicolumn{4}{|c|}{88.71} \\
\hline $\mathrm{CV}_{\mathrm{q}}$ & \multicolumn{4}{|c|}{49.44} \\
\hline
\end{tabular}


could stay over the leaf, adhered, spread or even runoff. According to Van Zyl et al. (2010) depending of the surfactant concentration, the values of surface tension could become lower and them may cause excessive spreading with droplet runoff. This could justify the lower values of deposition in the treatments that had more products than the insecticide.

The deposition was higher in Q2 and Q4 as expected (Table 5), mainly because the direction of application and the leaves overlay of Q1 and Q3 from the border plants. Tavares et al. (2017) found similar results when evaluated electrostatic application in guava trees, being that the quadrants that received direct application more deposition than the others that did not receive it.

On the first application, the treatments presented almost the same standard from spray losses to the soil in all quadrants, except the lower loss on Q2, for the treatment with all products and the treatment with Imid + $\mathrm{MnSO}_{4}$ (Table 6). Then again, for the second application Imid + Sil. and the treatment with all products presented similar losses to the soil in all quadrants. The treatments with only the insecticide had more losses in Q1, by the

Table 7: ANOVA summary for pest evaluation

\begin{tabular}{|c|c|c|c|c|c|c|c|c|}
\hline \multicolumn{9}{|c|}{ Nymph number (average) } \\
\hline & \multicolumn{4}{|c|}{$1^{\text {st }}$ application } & \multicolumn{4}{|c|}{$2^{\text {nd }}$ application } \\
\hline & 0 Daa & 7 Daa & 12 Daa & 14 Daa & 0 Daa & 7 Daa & 12 Daa & 14 Daa \\
\hline Ftreat & $1.694^{\mathrm{ns}}$ & $0.797^{\mathrm{ns}}$ & $1.014^{\mathrm{ns}}$ & $3.248^{*}$ & $1.379^{\mathrm{ns}}$ & $3.001^{\mathrm{ns}}$ & $5.578 *$ & $10.709 *$ \\
\hline Fquad & $0.967^{\mathrm{ns}}$ & $0.137^{\mathrm{ns}}$ & $3.011^{*}$ & $7.121 *$ & $6.648 *$ & $5.856^{*}$ & $1.989^{\mathrm{ns}}$ & $2.498^{\mathrm{ns}}$ \\
\hline Ftreat*quad & $2.070^{*}$ & $0.904^{\mathrm{ns}}$ & $1.012^{\mathrm{ns}}$ & $0.880^{\mathrm{ns}}$ & $1.656^{\mathrm{ns}}$ & $0.834^{\mathrm{ns}}$ & $0.482^{\mathrm{ns}}$ & $0.640^{\mathrm{ns}}$ \\
\hline Flevene & $2.057^{\mathrm{ns}}$ & $2.700^{\mathrm{ns}}$ & $1.419^{\mathrm{ns}}$ & $0.836^{\mathrm{ns}}$ & $1.678^{\mathrm{ns}}$ & $2.359^{*}$ & $5.640^{*}$ & $6.871 *$ \\
\hline SW & $0.947 *$ & $0.985^{\text {ns }}$ & $0.980^{\mathrm{ns}}$ & $0.948^{*}$ & $0.972^{\mathrm{ns}}$ & $0.971^{\mathrm{ns}}$ & $0.815^{*}$ & $0.915^{*}$ \\
\hline \multicolumn{9}{|c|}{ Psyllid infestation (\%) } \\
\hline & \multicolumn{4}{|c|}{$1^{\text {st }}$ application } & \multicolumn{4}{|c|}{$2^{\text {nd }}$ application } \\
\hline & 0 Daa & 7 Daa & 12 Daa & 14 Daa & 0 Daa & 7 Daa & 12 Daa & 14 Daa \\
\hline Ftreat & $0.917^{\mathrm{ns}}$ & $2.248^{\mathrm{ns}}$ & $8.917 *$ & $17.593 *$ & $0.422^{\mathrm{ns}}$ & $4.913^{*}$ & $4.608 *$ & $8.004 *$ \\
\hline Fquad & $0.105^{\mathrm{ns}}$ & $4.056^{*}$ & $1.947^{\mathrm{ns}}$ & $0.678 *$ & $0.717^{\mathrm{ns}}$ & $7.686^{*}$ & $2.400^{*}$ & $2.560^{\mathrm{ns}}$ \\
\hline Ftreat*quad & $1.369^{\mathrm{ns}}$ & $0.574^{\mathrm{ns}}$ & $1.113^{\mathrm{ns}}$ & $1.202^{\mathrm{ns}}$ & $1.111^{\mathrm{ns}}$ & $1.202^{\mathrm{ns}}$ & $1.403^{\mathrm{ns}}$ & $1.395^{\mathrm{ns}}$ \\
\hline Flevene & $1.200^{\mathrm{ns}}$ & $2.059^{\mathrm{ns}}$ & $2.548 *$ & $2.007^{\mathrm{ns}}$ & $1.718^{\mathrm{ns}}$ & $1.532^{\mathrm{ns}}$ & $2.221 *$ & $1.540^{\mathrm{ns}}$ \\
\hline SW & $0.945^{*}$ & $0.979^{\text {ns }}$ & $0.972^{\mathrm{ns}}$ & $0.971^{\mathrm{ns}}$ & $0.972^{\mathrm{ns}}$ & $0.975^{\mathrm{ns}}$ & $0.973^{\mathrm{ns}}$ & $0.951 *$ \\
\hline
\end{tabular}

F- Values of calculated $\mathrm{F}$ for different treatments. SW - Shapiro Wilk test. ns;* - not significant; significant at 0.05.

Table 8: Psyllid infestation (\%) in different tree quadrants

\begin{tabular}{|c|c|c|c|c|}
\hline \multirow{2}{*}{ Quadrants } & \multicolumn{4}{|c|}{$1^{\mathrm{a}}$ application } \\
\hline & O daa & 7 daa & 12 daa & 14 daa \\
\hline 1 & 37.50 & $48.75 \mathrm{~B}$ & 36.25 & 27.50 \\
\hline 2 & 32.50 & $26.25 \mathrm{~A}$ & 33.75 & 35.00 \\
\hline 3 & 37.50 & $47.50 \mathrm{~B}$ & 40.00 & 27.50 \\
\hline 4 & 35.50 & $22.50 \mathrm{~A}$ & 20.00 & 22.50 \\
\hline$\overline{C V_{t}}$ & 84.75 & 70.91 & 59.76 & 63.25 \\
\hline $\mathrm{CV}_{\mathrm{q}}$ & 68.97 & 72.71 & 86.00 & 88.02 \\
\hline \multirow{2}{*}{ Quadrants } & \multicolumn{4}{|c|}{$2^{\mathrm{a}}$ application } \\
\hline & 0 daa & 7 daa & 12 daa & 14 daa \\
\hline 1 & 42.50 & $27.50 \mathrm{~A}$ & $23.75 \mathrm{~A}$ & 22.50 \\
\hline 2 & 55.00 & $58.75 \mathrm{~B}$ & $37.50 \mathrm{~B}$ & 35.00 \\
\hline 3 & 52.50 & $22.50 \mathrm{~A}$ & $21.25 \mathrm{~A}$ & 16.25 \\
\hline 4 & 52.50 & $41.25 \mathrm{~B}$ & $37.50 \mathrm{~B}$ & 28.75 \\
\hline$\overline{C V_{t}}$ & 73.11 & 46.05 & 90.89 & 69.13 \\
\hline $\mathrm{CV}_{\mathrm{q}}$ & 57.85 & 69.83 & 83.91 & 68.02 \\
\hline
\end{tabular}

CV - Coefficient of variation; $\mathrm{t}$ - values of treatment; q- values of quadrant; F- values of calculated F for different treatments. ${ }^{\mathrm{ns}}$; ${ }^{-}$- not significant; significant at 0,05 ; Means followed by the same letter do not differ, in the column, according to Scott Knott ( $\mathrm{p} \leq 0.05$ ).

Rev. Ceres, Viçosa, v. 66, n.4, p. 297-306, jul/aug, 2019 
way when the adjuvant was added the losses became higher on Q3 and Q4 (Table 5).

The outcomes were similar to Tavares et al. (2017) when they evaluated standard application in guava trees with the same equipment and spray volume.

\section{Pest evaluation}

From the analyzed variables for pest evaluation (nymph number and infestation) the results were significant $(\mathrm{P}<0.05)$, according with the different evaluation period as showed in Table 7.

On the first application, the percentage of infestation 7 Daa was higher on Q1 and Q3. Differently from the second application that the \% infestation was higher on the Q2 and Q4. These results have a relation with the deposit of tracer in quadrants, showing that, in this case the quadrants that received more deposit presented a reduction of the percentage of infestation.

On the second period of the experiment, the plants present reduced number of leaves because of the climate and the overlay of the branches of the neighbor plants on Q1 and Q3, that did not happen in the first period because the size of the trees (Table 8).

Different from infestation, the number of nymphs presented higher values on Q2 and Q4 on the first period of application (Table 9). On the second application, on 0

Table 9: Psyllid Nymph (average) according to each different tree quadrant

\begin{tabular}{|c|c|c|c|c|}
\hline \multirow{2}{*}{ Quadrants } & \multicolumn{4}{|c|}{$1^{\text {st }}$ application } \\
\hline & 0 daa & 7 daa & 12 daa & 14 daa \\
\hline 1 & 3.25 & 2.05 & $2.60 \mathrm{~A}$ & $2.95 \mathrm{~A}$ \\
\hline 2 & 2.10 & 2.45 & $5.80 \mathrm{~B}$ & $8.60 \mathrm{~B}$ \\
\hline 3 & 2.10 & 2.00 & $2.85 \mathrm{~A}$ & $2.55 \mathrm{~A}$ \\
\hline 4 & 2.25 & 2.40 & $4.15 \mathrm{~B}$ & $6.70 \mathrm{~B}$ \\
\hline$\overline{\mathrm{CV}_{\mathrm{t}}}$ & 73.24 & 79.14 & 57.89 & 68.85 \\
\hline $\mathrm{CV}_{\mathrm{q}}$ & 75.12 & 25.16 & 71.31 & 57.50 \\
\hline \multirow{2}{*}{ Quadrants } & \multicolumn{4}{|c|}{$2^{\text {nd }}$ application } \\
\hline & 0 daa & 7 daa & 12 daa & 14 daa \\
\hline 1 & 10.35 & $2.25 \mathrm{~A}$ & 0.70 & 1.45 \\
\hline 2 & 7.90 & $16.50 \mathrm{~B}$ & 2.40 & 3.00 \\
\hline 3 & 7.79 & $3.90 \mathrm{~A}$ & 0.65 & 0.85 \\
\hline 4 & 3.35 & $13.90 \mathrm{~B}$ & 2.35 & 2.00 \\
\hline$\overline{\mathrm{CV}_{\mathrm{t}}}$ & 64.62 & 69.27 & 59.79 & 68.88 \\
\hline $\mathrm{CV}_{\mathrm{q}}$ & 53.12 & 53.06 & 86.00 & 72.10 \\
\hline
\end{tabular}

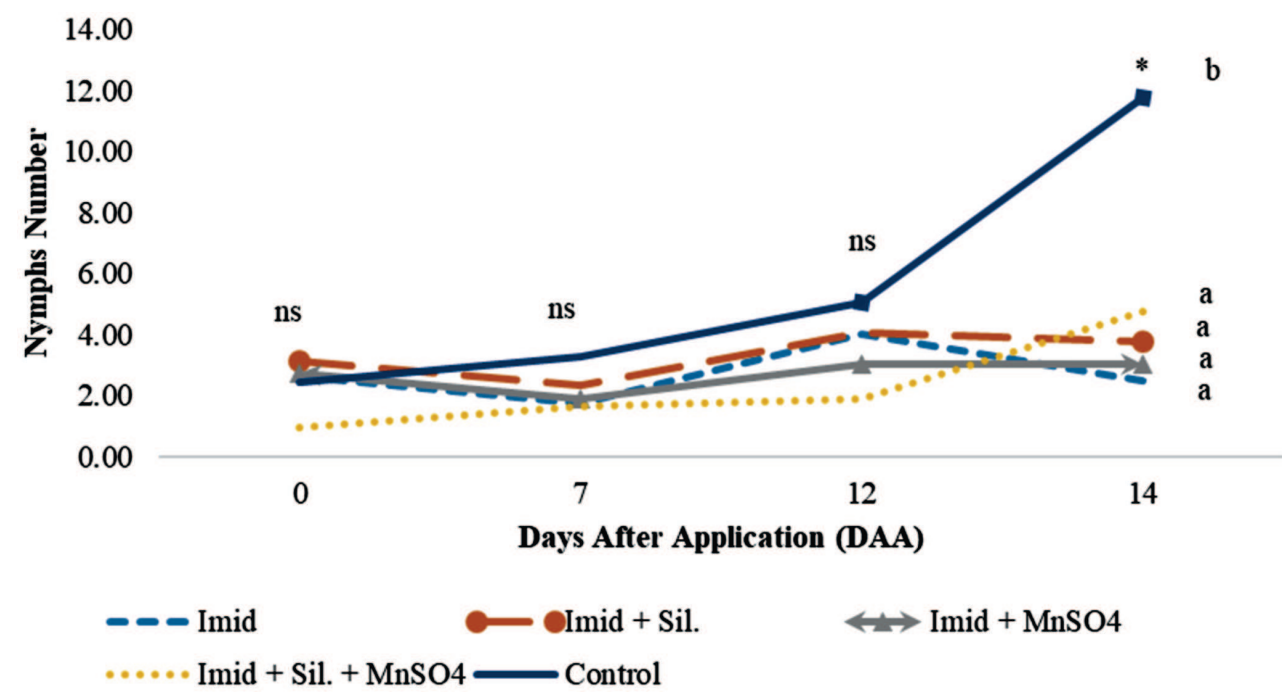

Figure 2: Average nymph number after the treatment applications $\left(1^{\text {st }}\right.$ period$) .^{\text {ns. }}$ * - not significant; significant at 0,05 .; Means followed by the same letter do not differ according to Scott Knott ( $\mathrm{p} \leq 0.05)$. 
Daa, the distributions of nymphs were similar in all quadrants. However, at 7 Daa the number of nymphs reduced in Q1 and Q3 and increased in Q2 and Q4 (Table 9).

Marcelino \& Barbosa (2016) found that T. limbata adults showed a moderate to highly aggregated distribution in all phases of guava, independently of the average size of the population, which could justify the higher number of nymphs in the quadrants 2 and 4 that had more leaves.

According to Figure 2, the number of nymphs where similar after the treatments application. On 14 Daa the number of nymphs had increased on the control treatment, differing from the others that had the same average, presenting that the insecticide had effect over the insects until this time.

On the second application, the number of nymphs fluctuated until the 12 DAA. Only on 14 Daa that the treatments presented difference in control. On this application the number of nymphs had been reduced from the treatments with the insecticide, except the mixture of it and the foliar fertilizer, that presented a difference between the other ones and the control too (Fig 3).

Galli et al. (2014) found that cv "Paluma" and "Rica" where the most attacked by the psyllid comparing with different accesses, some commercials and others in test. The percentage of damage were higher than $50 \%$ during all the experiment.

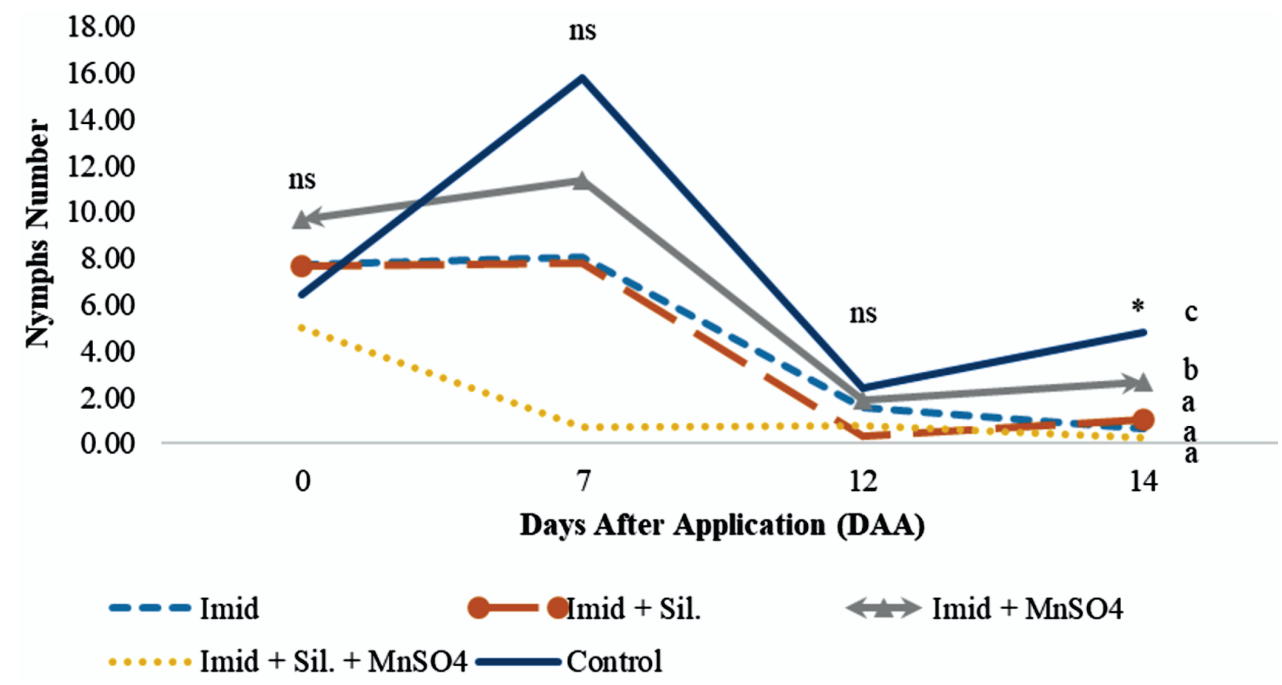

Figure 3: Average nymph number after the treatment applications $\left(2^{\text {nd }}\right.$ period $){ }^{\text {ns }}{ }^{*} *$ not significant; significant at $0.05 . ;$ Means followed by the same letter do not differ according to Scott Knott $\mathrm{p} \leq 0.05$.

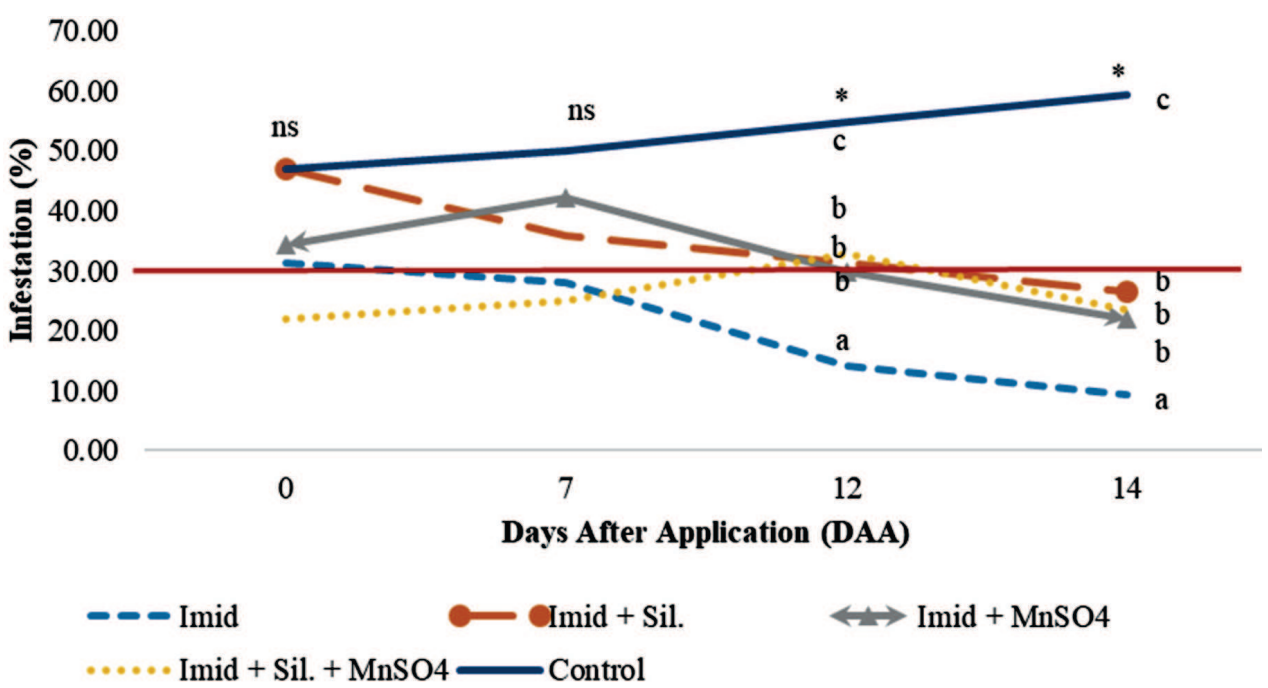

Figure 4: Leaves infested $(\%)$ by psyllid in guava trees $\left(1^{\text {st }}\right.$ period $) .{ }^{\text {ns; }} *$ - not significant; significant at 0.05 .; Means followed by the same letter do not differ according to Scott Knott $(\mathrm{p} \leq 0.05)$. 


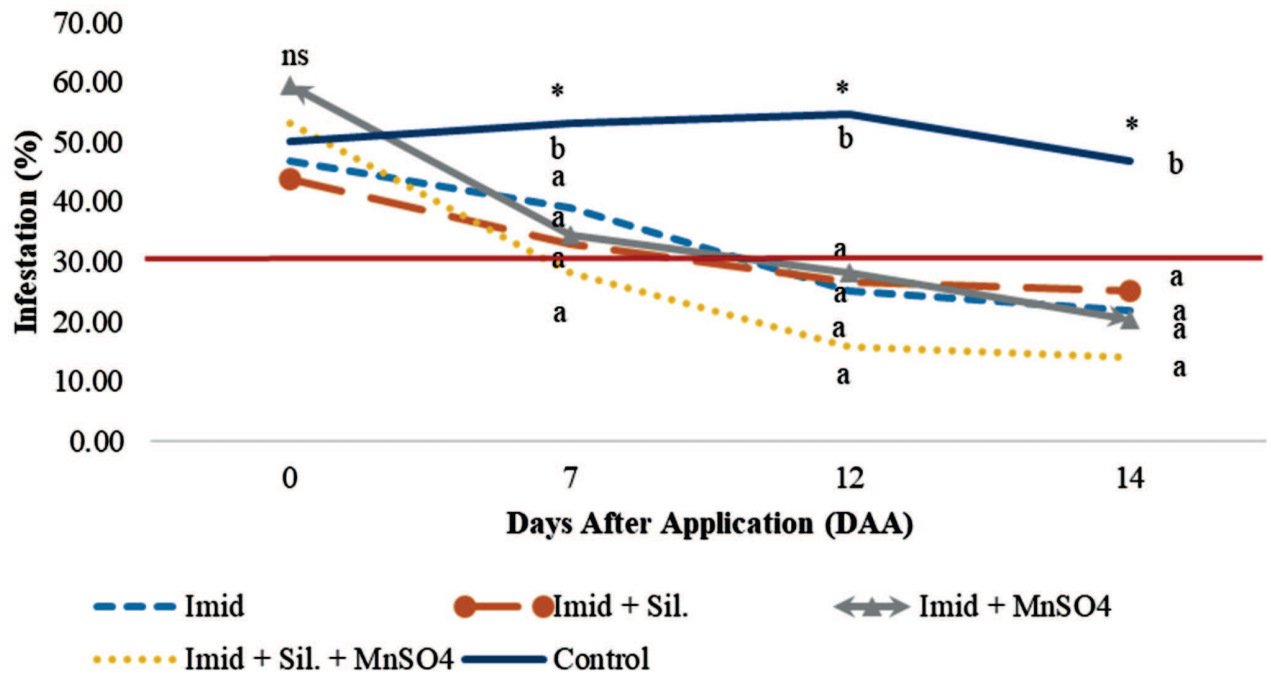

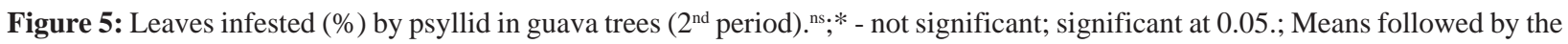
same letter do not differ according to Scott Knott $\mathrm{p} \leq 0.05$.

The damage threshold of $30 \%$ was achieved and the applications were necessary on both periods (Fig 4 and 5). These levels reduced on the 12 and 14 Daa, except for the control (Fig 4) on the first period and starting from 7 until 14 Daa on the second application (Fig 5). On both situations, the damage threshold was reduced above the recommended to another application, which justify only one in each period.

The first application all treatments reduced the $\%$ of infestation but the treatment with only insecticide reduced more than the others (Fig 4). This does not happen on the second application, when all the treatments reduced the infestation to the same level, becoming only different from the control (Fig 5). As we can see in Table 4, the foliar deposition of the treatment with only insecticide was higher than the others, justifying this difference between the treatments in the first application.

When applied over high density levels (higher than $50 \%$ ) and with an interval of 15 days between applications, the insecticide imidacloprid did not reduced the infestation levels above the damage threshold (Lima \& Gravina, 2009).

\section{CONCLUSION}

The addition of foliar fertilizer on the mixture reduced the $\mathrm{pH}$ and surface tension and increased the electric conductivity and viscosity of the insecticide solutions. The silicon adjuvant reduced the surface tension and increased the viscosity and the $\mathrm{pH}$. The quadrants that receive direct application (2 and 4) present higher spray deposition. All the treatments and quadrants present almost the same spray losses to the soil.

The number of nymphs as well as the infestation level decrease with the treatments applications. The tank mixture of organosilicon adjuvant and manganese foliar fertilizer do not influence the efficacy level of the insecticide.

\section{ACKNOLEDGEMENTS}

The authors would like to thank CNPq, CAPES and FAPEMIG for the financial support.

\section{REFERENCES}

Andrade DJ, Ferreira MC \& Fenólio LG (2013) Compatibilidade entre acaricidas e fertilizantes foliares em função de diferentes águas no controle do ácaro da leprose dos citros Brevipalpus phoenicis. Revista Brasileira de Fruticultura, Jaboticabal, 35:39-50

Barbosa FR \& Lima MF (2010) A cultura da goiaba. 2a ed. Brasília, Embrapa Informação Tecnológica. 180p

Barbosa FR, Souza EA, Siqueira KMM, Moreira WA, Alencar JR \& Haji FNP (2001) Eficiência e seletividade de inseticidas no controle de psilídeo (Triozoida sp.) em goiabeira. Pesticidas: Revista de Ecotoxicologia e Meio Ambiente, Curitiba, 11:45-52.

Bernards M, Thelen K, Penner D, Muthukumaran R \& McCracken J (2005) Glyphosate interaction with manganese in tank mixtures and its effect on glyphosate absorption and translocation. Weed Science, 53:787-794.

Colombi CA \& Galli JC (2009) Dinâmica populacional e evolução de dano de Triozoida limbata (Hemiptera: Psillydae) em goiabeira, em Jaboticabal, SP. Ciência Agrotecnologia, 33:412416

Cunha JPAR \& Alves GS (2009) Características físico-químicas de soluções aquosas com adjuvantes de uso agrícola. Interciência, 34:655-659.

Cunha JPAR, Bueno MR \& Ferreira MC (2010A) Espectro de gotas de pontas de pulverização com adjuvantes de uso agrícola. Planta Daninha, 28, 1153-1158.

Cunha JPAR, Alves GS \& Reis EF (2010B) Efeito da temperatura nas características físico-químicas de soluções aquosas com adjuvantes de uso agrícola. Planta Daninha, 28:665-672. 
Farias WC, Câmara FMM, Silva FSO, Mendonça V, Pereira GA \& Leite GA (2017) Qualidade de frutos da goiabeira cv. Paluma submetida a podas de frutificação em diferentes épocas no município de Mossoró-RN. Nativa, 05:05-08.

Fernández V \& Eichert T (2009) Uptake of hydrophilic solutes through plant leaves: current state of knowledge and perspectives of foliar fertilization. Critical Review in Plant Science, 28:3668.

Galli JA, Michelotto MD, Soares MBB, Martins ALM \& Fischer IH (2014) Damage Caused by Psyllids and Influence of Climatic Factors in Brazilian Accesses of Guava Trees Cultivated in Organic System. American Journal of Plant Sciences, 05:1432.

Gallo D, Nakano O, Silveira Neto S, Carvalho RPL, Batista GC, Berti Filho E, Parra JRP, Zuchi RA, Alves SB, Vendramim JD, Marchini LC, Lopes JRS \& Omoto C (2002) Entomologia agrícola. Piracicaba, FEALQ. 920p

Gazziero DLP (2015) Mistura de agrotóxicos em tanque nas propriedades agrícolas do Brasil. Planta Daninha, Viçosa, 33:8392.

Iost CAR \& Raetano CG (2010) Tensão superficial dinâmica e ângulo de contato de soluções aquosas com surfatantes em superfícies artificiais e naturais. Engenharia Agrícola, 30:670680.
Khaliq A, Matloob A, Mahmood S, Abbas RN \& Khan MB (2012) Seeding density and herbicide tank mixtures furnish better weed control and improve growth, yield and quality of direct seeded fine rice. International Journal of Agriculture and Biology, 14:499-508

Lima JOGD \& Gravina GDA (2009) Failure of imidacloprid and thiacloprid to control the guava-psyllid, Triozoida limbata (Enderlein) (Hemiptera: Psyllidae). Ciência e Agrotecnologia, 33:1888-1891.

Marcelino MCS \& Barbosa JC (2016) Spatial distribution of adults of Triozoida limbata (Enderlein) (Hemiptera: Triozidae) in guava plants. Neotropical entomology, 45:123-128.

Tavares RM, Cunha JPAR, Alves TC, Bueno MR, Silva SM \& Zandonadi CHS (2017) Electrostatic spraying in the chemical control of Triozoida limbata (Enderlein) (Hemiptera: Triozidae) in guava trees (Psidium guajava L.). Pest management science, 73:1148-1153.

Van Zyl SA, Brink JC, Calitz FJ, Coertze S \& Fourie PH (2010) The use of adjuvants to improve spray deposition and Botrytis cinerea control on Chardonnay grapevine leaves. Crop Protection, 29:58-67.

Wang CJ \& Liu ZQ (2007) Foliar uptake of pesticides-present status and future challenge. Pesticide Biochemistry and Physiology, 87:01-08. 